\title{
Review
}

\section{Building power to change the world: The political thought of the German council movement}

\author{
James Muldoon,
}

Oxford University Press,

Oxford, 2020, 208 pp., ISBN: 9780198856627

Contemporary Political Theory (2022) 21, S106-S109. https://doi.org/10.1057/s41296021-00512-x; published online 11 August 2021

What alternatives were forgotten when democracy became reduced to parliamentary representation? James Muldoon's excellent book Building Power to Change the World: The Political Thought of the German Council Movement returns to a critical moment at the end of World War I when the form of democracy was a live political question. During the revolutionary upheavals at the end of the war, workers and soldiers spontaneously created self-governing councils amidst the wreckages of European states.

These councils inspired a vigorous debate among observers, and especially the intellectuals of various European socialist parties. Muldoon carefully reconstructs the thought of three of the most instructive socialist theorists of the council movement - Anton Pannekoek, Karl Kautsky, and Rosa Luxemburg - to show that the ideal of council democracy can provide a critical vantage point from which to evaluate our current moment. Muldoon's book is an act of historical recovery, one that uses history to 'denaturalize' our present political arrangements. In this case, he seeks to denaturalize our horizon of parliamentary democracy and recover the alternative that arose during those heady days following the collapse of the German imperial government at the end of WWI.

Muldoon also breathes life back into those debates. The book contributes to the burgeoning literature on 'socialist republicanism,' which shows how workers and socialist thinkers built on the broader republican ideal of freedom as nondomination. In particular, he examines how these socialist thinkers and activists drew on and enriched a larger tradition of democratic republican theorizing. While each chapter is organized around a thinker, in each case Muldoon shows how their thought addresses a specific concept within republican political thought: freedom, power, organization, and civic virtue. In all, Muldoon argues that these reflections on council democracy reveal an alternative model of politics. In contrast to many

(c) 2021 The Author(s), under exclusive licence to Springer Nature Limited. 1470-8914 Contemporary Political Theory Vol. 21, S3, S106-S109

www.palgrave.com/journals 
subsequent participatory and deliberative democrats, council democrats were centrally focused on issues of power and mass mobilization. But they sought to combine that focus on mobilization with concrete reflection on the institutional form of radical democracy.

Muldoon begins with the emergence of the workers' and soldiers' councils after WW I. With political power collapsing under the weight of the disastrous war, workers and soldiers throughout Russia and Germany instinctively formed democratic councils to run the country. In this respect, one thing from which the book would have benefited is more detail on the day-to-day operation of the councils and how participants within them balanced administrative questions with their larger political goals.

The core of the book is an engagement with three of the key theorists of the council movement: Anton Pannekoek, Karl Kautsky, and Rosa Luxemburg. As canonical theorists of council democracy, Pannekoek and Luxemburg are obvious inclusions. Yet one surprise of the book is the extent to which Kautksy becomes the hero of the story, and one of its major achievements is to revise Kautksy's standing, scraping away the crust of polemical misreadings. In Muldoon's hands, each theorist becomes a contributor to larger debates within political theory.

First, Pannekoek presents an important theorization of the relationship between council democracy and freedom. For him, councils embody freedom as an activity and not a condition or a status. Freedom requires active self-determination through participation in common affairs. This appears close to a positive view of freedom, where participation in politics realizes something essential for us. But, according to Muldoon, this is not so, as Pannekoek is not concerned with autonomous selfcontrol. Rather, his ideal of freedom focuses on the collective overcoming of impediments to our freedom - that is, it is not a matter of our internal psychological states but of how freedom is manifested in the world. Furthermore, the key goal is not participation as such but collective control over collective institutions.

While these theorists were advocates of participation and democracy, unlike many subsequent participatory democrats they were also socialists, and so for them micro-level participation was always connected to the larger question of the organization of workers' power. Muldoon next examines the conception of power used in these debates, showing how council democracy was meant to contribute to the larger construction of power among workers. Yet here we first start to see the fissures in the debate about council democracy, with the key question becoming the autonomy of the organization and activity of the masses vis-à-vis both formal parties and the state.

This brings us to what in my view is the most intriguing chapter in the book. Muldoon examines Karl Kautsky as a theorist of socialist republicanism. We know Kautsky as one of the most deterministic theorists of Marxism during the period of the Second International, committed to the idea that revolutionary politics could only occur in moments of capitalist crisis. Muldoon reveals a much more dynamic

(C) 2021 The Author(s), under exclusive licence to Springer Nature Limited. 1470-8914 Contemporary $\quad$ S107 Political Theory Vol. 21, S3, S106-S109 
Kautsky, one who envisioned a complementary role for parliamentary democracy, municipal de-centralization, and direct participation through various councils. Also notable here are Kautksy's critiques of the ideal of full council democracy. He worried that, on their own, councils risk privileging a small segment of workers and soldiers, namely those with the ability and time to actively participate in the councils. In contrast, universal suffrage, even as it is weaker from a participatory perspective, can be more inclusive.

Muldoon ends with Luxemburg - no doubt the most well-known theorist to emerge from the council debate. Muldoon finds in Luxemburg a theory of civic virtue. Luxemburg here appears as an important voice in a longer tradition of thinking about how good politics relies on good citizens. A crucial part of mass mobilization and struggle for her was pedagogical: it helped individuals come to see themselves as active participants in public life, rather than passive or obedient. For Luxemburg, the power and participation of the masses was not enough. They also needed to overcome their habituation to obedience in the factory and see themselves as authors of their own life. Particularly notable here is Luxemburg's polemics with Lenin. While Lenin praised the discipline of the factory, Luxemburg sought to distinguish between self-imposed, conscious discipline and the external discipline of obedience.

What we get, in the end, is a sense of the richness and depth of this forgotten debate about democracy, one that arose when the question of democracy's form was genuinely unsettled. Yet there are several aspects of Muldoon's argument that, to my mind, remain open. In part, this reflects the ambivalence of the thinkers under consideration. But I wanted to hear more about how Muldoon sees these ambivalences as being potentially resolved in a view of council democracy with contemporary relevance.

The deepest tension in the argument revolves around the question whether councils are a supplement to parliamentary democracy or a substitution for it. On one side are Luxemburg and Pannekoek, who both seem to see council democracy as a self-contained alternative to parliamentary democracy. On the other side is Kautsky, who believed in parliamentary democracy but thought that parliaments required constant external pressure and independent mobilization to avert elitism. The book leaves Muldoon's position on this debate open. I also wanted to hear more sustained analysis of, or response to, Kautksy's democratic concerns about councils. Kautsky worries that councils will end up being partial, easily captured by segments of the working class, and so not genuinely inclusive and universal. Parliamentary action can provide that universality, while councils can provide robust checks on parliament. Does Muldoon find this vision compelling?

Behind this debate about councils as supplement or alternative is a disagreement about the relationship between political conflict and class unity. The pro-council side of the debate has a stronger background notion of class identity, and it is this idea of class identity that makes them more optimistic about the ability to replace 
parliamentary democracy with council democracy. If there is a united interest of the working class, then it is less important if some people are occasionally excluded from the councils, as those present will speak for all workers. In contrast, Kautsky worries about the lack of automatic class unity. He believes that, given their more local nature, some workers could try to use institutions like councils to their advantage. As a result, councils need to be checked through other democratic institutions that are better at balancing diverse interests in society. And this conflict is not due to insufficient class consciousness but very basic institutional facts about the difficulty of coordinating economic and political decisions among plural actors, such that some actors will quite naturally privilege their own interests if not sufficiently checked. Again, I wanted to hear more of Muldoon's own analysis of these issues, all of which seem vital for reviving council democracy today.

Yet none of this should detract from Muldoon's achievement. In his careful hands, the tradition of council democracy becomes a nuanced and sophisticated perspective from which to critique representative government. Muldoon also reminds us that the socialist movement inspired a vibrant debate about democracy, often couched in the language of the republican tradition, but which stands as an alternative to the 'Atlantic' republicanism associated with thinkers like Quentin Skinner and Philip Pettit. By returning us to a moment when the institutional form of democracy was genuinely unresolved, Muldoon shows that the history of political thought can produce powerful resources for questioning the present.

Publisher's Note Springer Nature remains neutral with regard to jurisdictional claims in published maps and institutional affiliations.

Steven Klein

Department of Political Economy, King's College London, London WC2R 2LS, UK steven.klein@kcl.ac.uk 